\title{
Characterising policy responses to complex socio-ecological problems: 60 fire management interventions in Indonesian peatlands
}

Una Jefferson1, Rachel Carmenta1,2, Willy Daeli13, Jacob Phelps4

1. Center for International Forestry Research (CIFOR), Bogor, Indonesia

2. University of Cambridge Conservation Research Institute, Department of Geography, University of Cambridge

3. World Resources Institute Indonesia (WRI), Kebayoran Baru, Jakarta Selatan, Indonesia

4 Lancaster Environment Centre, Library Avenue, Lancaster University, Lancaster LA1 4YQ, United Kingdom

\section{Acknowledgements}

Thank you to Ramadhani Achdiawan, Aiora Zabala, Saut Sagala, Made Ali, Shita Pina Saphira, Arief Wijaya, Dewi Tresya, Herry Purnomo, Bradford Sanders, Mubariq Ahmad. This research was made possible under the support from the UK Department for International Development (Dfid) project to the Centre for International Forestry Research project on the Political Economy of Fire and Haze in Indonesia (No 203034) and the Frank Jackson Foundation.

\section{Competing interests statement}

Declarations of interest: none 


\section{Introduction}

Pressing socio-ecological problems, such as climate change, deforestation and chronic wildfire, present unique governance challenges (Padt et al. 2014; Jordan et al. 2015). They occur at multiple scales, affect diverse sectors, and have uncertain, controversial, and unevenly distributed impacts (e.g., Barlow et al, 2018; Marino and Ribot 2012; Ostrom 2010).

These challenges have elicited a broad range of interventions and, over the past two decades, many new governance arrangements have complemented, competed with, and occasionally transformed traditional government interventions (Jordan et al. 2005; Cashore et al. 2004; Doelle et al. 2012; Lambin et al. 2014; Obidzinski and Kusters 2015). Faced with this increasing governance "messiness", there is an urgent need to document and analyse these interventions. Despite a wealth of case studies, there are few large-scale, structured descriptions and comparative analyses of the diverse interventions that respond to complex socio-ecological problems. Such contributions are prerequisite to identifying which types of interventions lead to improved environmental and social outcomes, asking for example whether factors like non-state involvement or "multi-level" decision-making (i.e. involving a variety of scales or sectors) improve outcomes (Koontz and Thomas 2006; Newig and Fritsch 2009; Huitema et al. 2009).

Scholars across contexts have explored variables that might shape intervention performance (see Table 1; IFRI 2018). This has included, for example, recognising the mismatch between traditional centralized, hierarchically-ordered approaches to rulemaking and program design, and the realworld complexity of environmental problems (Ostrom 2010; Young 2002; McCarthy and Zen 2009; Termeer et al. 2010; Stewart et al. 2013). Scholars have highlighted the benefits of more diverse interventions that better reflect the complexity of socio-ecological problems (Young 2002; McCarthy and Zen 2009; Padt et al. 2014; Termeer et al. 2010; Stewart et al. 2013). Scholars have prescribed greater involvement of non-state actors, including arguments that private sector participation may improve intervention performance through market incentives and greater public participation (e.g., Anderson and Leal 1991, Forsyth 2010). Further, studies have highlighted that intervention outcomes can improve when diverse institutions with overlapping jurisdictions address a problem (e.g., Cash et al. 2006; Ostrom 2010). Importantly, scholars have identified the relevance of "targeting" to improve the performance of interventions: essentially, narrowing the parameters in which interventions apply in order to allocate resources to the specific stakeholders, sites, and times where they will be most impactful (see references in Table 1). For example, interventions from non-government or multilevel institutions are often more targeted, which can improve outcomes but may also introduce higher transaction costs and scaling challenges (e.g., Ostrom, Tiebout and Warren 1961; Wünscher et al. 2006; Wünscher et al. 2008; Sattler et al. 2013).

There is a need to make greater sense of the ensuing crowded intervention arenas - of interventions that engage different scales, sectors, and strategies. Such efforts should identify relevant interventions and systematically document their characteristics. This paper undertakes that work for Fire Management Interventions (FMI) to address chronic peat fires in Indonesia. Uncontrolled tropical fires are increasing in prevalence globally (Jolly et al.), including severe fires in the Brazilian Amazon and Indonesian peatlands at the time of writing. Peat fires in Indonesia 
are a complex socio-environmental problem that have motivated a large number of diverse fire management interventions (FMI) from government, industry, and civil society over the past three decades (Dennis 1999; Padfield et al. 2016; Tacconi, 2016). We describe "who is doing what" to address Indonesia's peat fires, by (1) identifying and categorizing FMI, (2) grouping FMl according to their institutional characteristics, and (3) investigating how institutional types differed in terms of the design of the FMI they mandated. We anticipated that FMI would have low levels of targeting overall, specifically when it came to differentiating between types of landholders. We anticipated higher levels of targeting among some types of FMI, notably among those involving multi-level institutions and civil society. We also hypothesised that certain intervention strategies would be strongly associated with certain sectors, notably that the government interventions would primarily rely on regulatory strategies and industry on incentives. Where incentives were used, we anticipated that these would be limited to the private sector and that few would include elements of conditionality.

"Stock-taking" of this intervention arena is timely, given the recent proliferation of new interventions as fires worsen. This study also contributes to the rapidly developing literatures on multi-level and polycentric governance by comparing interventions from diverse institutions responding to a single problem. It lays the groundwork for future studies assessing the comparative performance of different types of $\mathrm{FMI}$, as it examines design variables suspected to affect performance (Table 1). Our comprehensive scope allows comparisons to be made across scales - geographic, political, and temporal - to an extent rare in the literature on the governance of complex socio-ecological problems (Newig and Fritsch 2009).

\section{Peat fire in Indonesia}

Extensive and increasingly frequent peat fires in Indonesia are causing severe carbon emissions, transboundary toxic smoke pollution (haze), ecosystem degradation, public health problems, economic losses, and diplomatic tensions in the ASEAN region (Yule 2008; Van der Werf 2015; Huijnen et al. 2016; Koplitz et al. 2016; Lohberger et al. 2017; Turetsky et al, 2014; Wijedasa et al. 2017). Although numerous interventions have attempted to address them since the 1980s, these peat fires have evaded a simple or universal solution (Dennis et al. 2005; Carmenta et al. 2017).

Large-scale wildfires are historically rare in moist tropical environments including Indonesia's peat swamp forests (Turetsky et al. 2014). Undisturbed peat is waterlogged and resistant to fire, but peatland which has been drained for plantation agriculture is highly flammable (Sloan et al, 2017). Historically, peatland has been widely regarded as unproductive marginal land in Indonesia (Persoon and Simarmata 2014), but advances in agricultural technology, rising international demand for commodities such as palm oil, and a lack of economic alternatives to cash crops have made peatland drainage and development profitable (McCarthy et al. 2012). Land use change on peatlands has created the conditions for large-scale conflagrations in Indonesia. Fires spread easily due to the high organic material content of peat soil, can smoulder for long periods at low intensities (making them difficult to detect using remote sensing), and can follow coal seams underground, creating conditions that challenge attempts to extinguish them (Whitehouse et al. 2004; Turetsky et al. 2014). These fire events were previously associated with El Niño Southern Oscillation (ENSO) years but have recently begun to occur in non-ENSO years as well (Gaveau et 
al. 2014; Sloan et al. 2017). Peat fires contribute disproportionately to toxic haze and carbon emissions, as compared to fires on mineral soils, and affect an extensive land area and large numbers of people in the ASEAN region (Miettinen et al. 2012; Marlier et al. 2015).

Traditionally, fire has been used in the agricultural practices of small-scale farmers in Indonesia, almost exclusively on mineral soils (Dove 1985). In contrast, today fire is used by new types of actors (e.g., immigrant farmers and absentee investors), at larger scales, and on new substrates with distinct ecological parameters - notably including peat soil (Chokkalingam et al. 2006; Cattau et al. 2016; Gaveau et al. 2017; Jelsma and Schoneveld 2016). Uncontrolled fire on peatland is exacerbated by failures of land use planning and law enforcement: fire is no longer used only for traditional agriculture but now may be used as retribution in land disputes, or where tenurial uncertainty removes incentives for careful management (Stolle et al. 2003; Dennis et al. 2005; Varkkey 2013). Fire remains the cheapest and most accessible method of land clearance and preparation (Ding et al. 2016), and a blanket ban on its use is not likely to be effective, efficient, or equitable (Carmenta et al, 2018). In order for FMI to succeed, controls on ignition and substrate flammability must contend with the perceived benefits of peatland conversion (FAO 2006

\section{Methods}

\subsection{Scope and inclusion criteria}

We gathered data on the institutional characteristics and design of all FMI addressing peatland fires in Riau Province, Sumatra (Figure 1), begun between January of 1999 and December of $2016(n=60)$. We compiled our sample and dataset through a desk review of policy content, project documents, and sustainability reports, and then expanded and verified them through expert consultations in Jakarta and Pekanbaru with representatives from academia, civil society, government and industry (Supplementary Table A). We included international- and national-level FMI that apply in Riau, and those that were specific to Riau. Riau was selected because it is a site of dramatic land use change for oil palm and pulpwood cultivation (Miettinen et al. 2016), where frequent fires have prompted numerous FMl from diverse actors (Gaveau et al. 2014; Supplementary Table B).

Figure 1. Map of peatland extent in Riau, Sumatra. Source: Global Forest Watch derived from Ministry of Agriculture. 


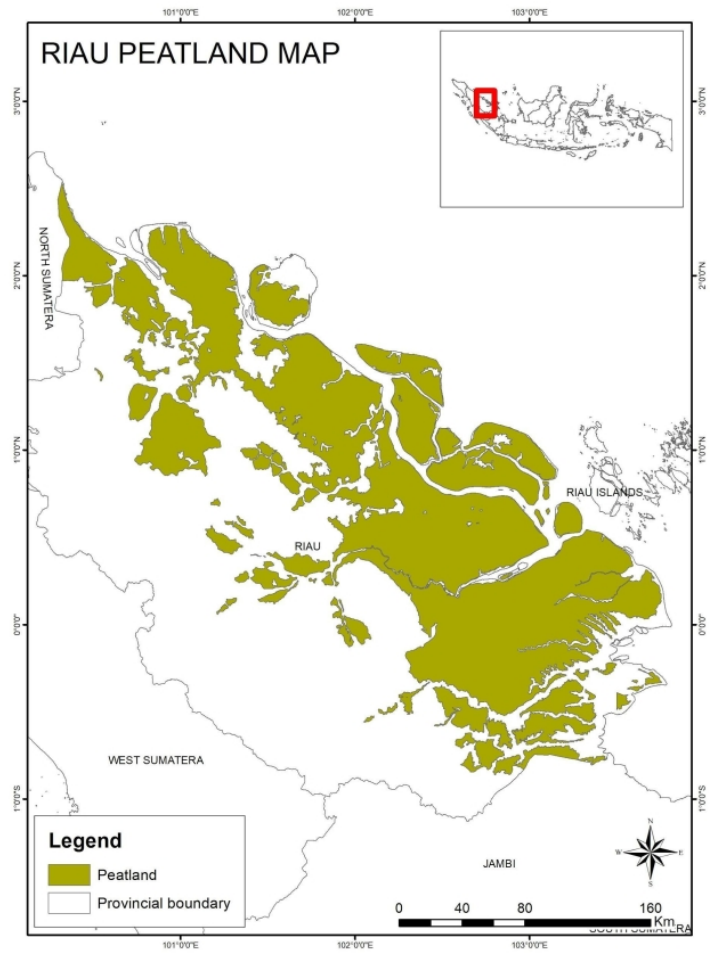

124

We included FMI with a stated intention to address peat fire, including those that addressed drivers (e.g., land tenure uncertainty) or undesirable outcomes (e.g., transboundary haze). We included FMI mandated by government, industry, and civil society, with geographic scales ranging from international to district-level. We included government regulations, decrees, and programs with provisions for enforcement and/or implementation (see section 2.2). We excluded enabling statutes (to avoid double-counting and counting unimplemented statutes), corporate sustainability pledges that were not clearly actioned, and advocacy campaigns. Our dataset contains no information on implementation or outcomes.

132

133

\subsection{Characterising FMI design}

To characterise FMI design, we assessed the literature to identify variables that were salient to the performance of FMI and of interventions addressing complex socio-ecological problems more broadly (Table 1). Through an iterative process, we refined our selection of variables to those that were also present in our dataset. We identified six variables for which information was available in the documentation of all 60 FMI: four describing FMI design (see Table 1) and two describing the institutional characteristics of FMI (Table 2).

\subsubsection{Intervention design}

We characterized each FMI according to its design (Table 1). The first design variable characterised FMI strategy according to four broad types: regulation and enforcement, incentives, technical solutions, and reform (adapted from Carmenta et al. 2017). Among FMI that used incentives, we also recorded whether the incentives were conditional; whether conditional incentives were triggered by inputs or results (e.g., fire occurrence or haze levels), and whether 
The second design variable captured the overall approach to fire mitigation by identifying whether FMl focused on preventing fires or responding to them (i.e. via fire-fighting) (or both). Thirdly, we identified the primary geographic scale of FMI implementation.

Finally, the fourth design variable recorded the degree to which FMI were designed to target highrisk soil types (i.e., peat soil), differentiate between types of landholders that have different relationships to fire; and target time periods of particularly high fire risk (e.g., ENSO years, dry seasons, midday). Research on the causes of fires and analyses of FMI performance have consistently emphasized that narrowing FMI applicability to these areas, actors and time periods would improve their effectiveness, efficiency, and equity (see Table 1).

Table 1: FMI intervention design variables

\begin{tabular}{|c|c|c|c|}
\hline Variable & Description & Values & Explanation and justification \\
\hline \multirow[t]{4}{*}{$\begin{array}{l}\text { Type of } \\
\text { intervention } \\
\text { strategy }\end{array}$} & $\begin{array}{l}\text { Regulation: } \\
\text { Does the FMI } \\
\text { use } \\
\text { regulatory } \\
\text { strategies? }\end{array}$ & yes, no & $\begin{array}{l}\text { Regulation-based interventions included } \\
\text { legislation, but also non-state interventions } \\
\text { that support enforcement through watchdog } \\
\text { activities (e.g., the NGO Jikalahari) }\end{array}$ \\
\hline & $\begin{array}{l}\text { Incentives: } \\
\text { Does the FMI } \\
\text { use } \\
\text { incentives? }\end{array}$ & yes, no & $\begin{array}{l}\text { This includes all FMI that attempt to change } \\
\text { behavior through the distribution of } \\
\text { conditional and unconditional benefits, either } \\
\text { in cash or in kind. } \\
\text { Incentives are often identified as a } \\
\text { mechanism driving improved performance } \\
\text { among private environmental interventions } \\
\text { (e.g., McCarthy and Zen 2009; Dryzek 1997; } \\
\text { Humphreys 2008). }\end{array}$ \\
\hline & $\begin{array}{l}\text { If the FMI } \\
\text { uses } \\
\text { incentives, } \\
\text { are these } \\
\text { conditional? }\end{array}$ & $\begin{array}{l}\text { condition } \\
\text { al, } \\
\text { unconditi } \\
\text { onal }\end{array}$ & $\begin{array}{l}\text { Conditional refers to the release of incentives } \\
\text { based on meeting a predefined requirement, } \\
\text { condition for the reward. Conditional cash } \\
\text { transfers are expected to be related to } \\
\text { improved performance (Wunder et al, 2018; } \\
\text { Wunder 2005). }\end{array}$ \\
\hline & $\begin{array}{l}\text { If the FMI } \\
\text { uses } \\
\text { incentives, } \\
\text { what triggers } \\
\text { their } \\
\text { disbursement } \\
?\end{array}$ & $\begin{array}{l}\text { [input- } \\
\text { based, } \\
\text { results- } \\
\text { based, } \\
\text { mixed] }\end{array}$ & $\begin{array}{l}\text { "Trigger" refers to the conditions that must be } \\
\text { met before conditional incentives are } \\
\text { disbursed. "Input-based" triggers require } \\
\text { conditions to be met that are indirectly related } \\
\text { to the desired result. "Results-based" triggers } \\
\text { disburse incentives when a desired result is } \\
\text { achieved (Sattler et al. 2013). }\end{array}$ \\
\hline
\end{tabular}




\begin{tabular}{|c|c|c|c|}
\hline & $\begin{array}{l}\text { Are eco- } \\
\text { labels used to } \\
\text { verify } \\
\text { sustainable } \\
\text { practices? }\end{array}$ & yes, no & $\begin{array}{l}\text { Eco-labels seek to promote sustainable } \\
\text { behaviours by providing consumers with } \\
\text { information about the social and } \\
\text { environmental impacts of their purchases. } \\
\text { They are one of the "'new' economic policy } \\
\text { instruments" (NEPI) becoming increasingly } \\
\text { popular in environmental governance } \\
\text { (Cashore et al. 2004; Jordan et al. 2005). }\end{array}$ \\
\hline & $\begin{array}{l}\text { Reform: Does } \\
\text { the FMI use } \\
\text { institutional } \\
\text { reforms to } \\
\text { address } \\
\text { fires? }\end{array}$ & yes, no & $\begin{array}{l}\text { This includes FMI making changes in } \\
\text { jurisdiction, administration, and resourcing } \\
\text { directly intended to improve fire management } \\
\text { (e.g., the } 2007 \text { version of the RSPO } \\
\text { establishing a complaint process, or } \\
\text { Presidential Instruction } 11 / 2015 \text { restructuring } \\
\text { the Regional Disaster Management Agency } \\
\text { with the goal of better responding to fires) }\end{array}$ \\
\hline & $\begin{array}{l}\text { Technical } \\
\text { solutions: } \\
\text { Does the FMI } \\
\text { use technical } \\
\text { solutions? }\end{array}$ & yes, no & $\begin{array}{l}\text { Examples of technical solutions to peat fires } \\
\text { include fire fighting and peatland rewetting }\end{array}$ \\
\hline $\begin{array}{l}\text { Approach to } \\
\text { fire mitigation }\end{array}$ & $\begin{array}{l}\text { Does the FMI } \\
\text { attempt to } \\
\text { prevent fires, } \\
\text { or respond to } \\
\text { them? }\end{array}$ & $\begin{array}{l}\text { preventio } \\
\mathrm{n} \text {, } \\
\text { response, } \\
\text { both }\end{array}$ & $\begin{array}{l}\text { Studies of FMI frequently distinguish } \\
\text { preventative from reactive measures (e.g., } \\
\text { Vayda 2010; Nurhidayah 2014). } \\
\text { Diverse stakeholders agree that preventative } \\
\text { instruments should be prioritized on peat soil } \\
\text { (Carmenta et al. 2017). }\end{array}$ \\
\hline $\begin{array}{l}\text { Geographic } \\
\text { scale }\end{array}$ & $\begin{array}{l}\text { At what } \\
\text { geographic } \\
\text { scale is FMI } \\
\text { implementatio } \\
\text { n planned? }\end{array}$ & $\begin{array}{l}\text { district, } \\
\text { provincial, } \\
\text { national, } \\
\text { internatio } \\
\text { nal }\end{array}$ & $\begin{array}{l}\text { This variable refers to the geographic scale } \\
\text { upon which FMI are designed to be } \\
\text { implemented. }\end{array}$ \\
\hline $\begin{array}{l}\text { Evidence of } \\
\text { targeting }\end{array}$ & $\begin{array}{l}\text { Soil type } \\
\text { targeting: } \\
\text { Does the FMI } \\
\text { treat peat soil } \\
\text { distinctly from } \\
\text { mineral soil? }\end{array}$ & yes, no & $\begin{array}{l}\text { Peat soil... } \\
\text { - } \\
\text { is more flammable when drained than } \\
\text { mineral soil (Turetsky et al. 2014); } \\
\text { undergoes combustion that is uniquely } \\
\text { difficult to extinguish (Turetsky et al. } \\
\text { 2014; Whitehouse et al. 2004); } \\
\text { has been the main source of toxic } \\
\text { smoke pollution and carbon emissions } \\
\text { from wildfires in Indonesia (Koplitz et } \\
\text { al, 2016; Sargeant 2001; Marlier et al. } \\
\text { 2015); and }\end{array}$ \\
\hline
\end{tabular}




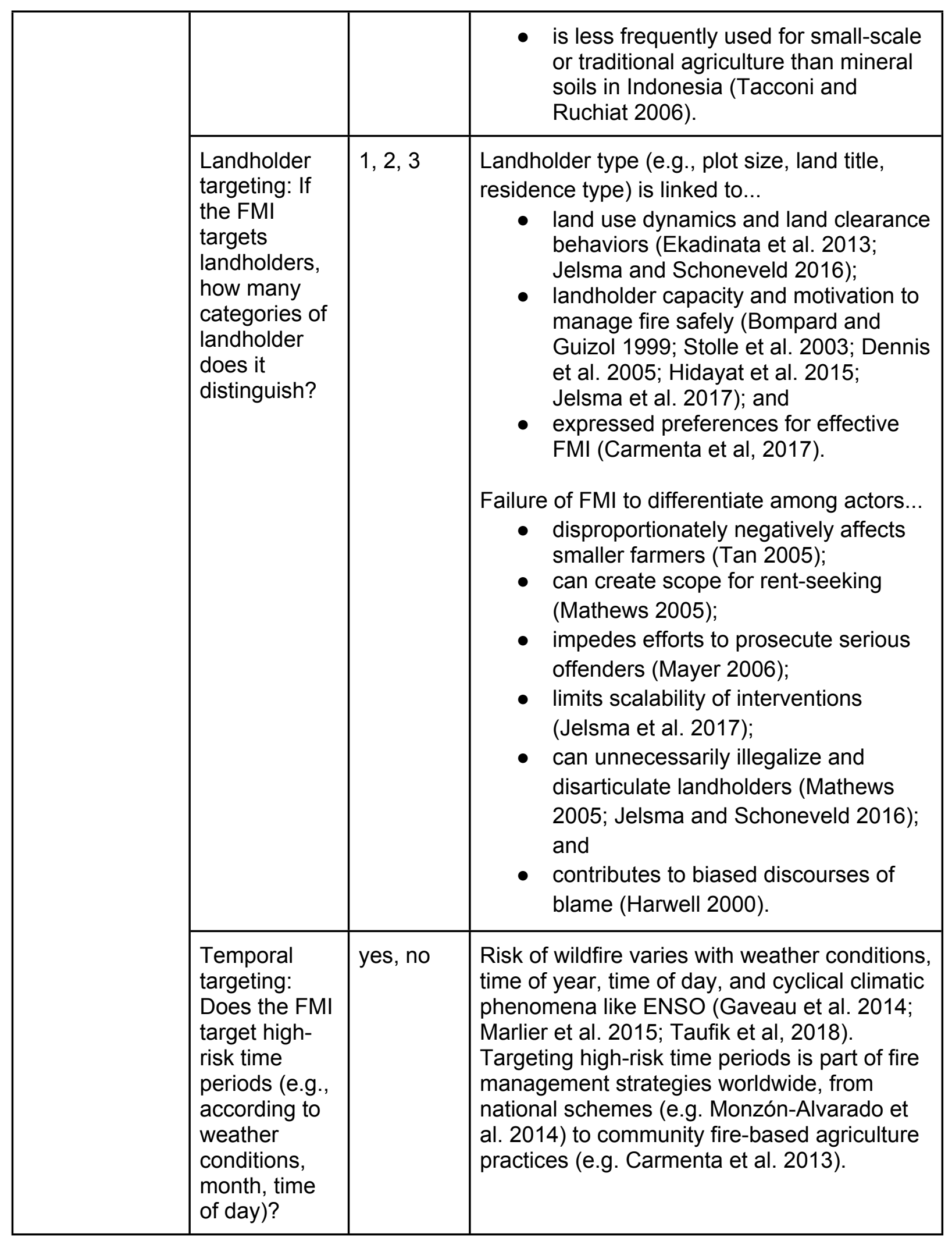


We used two variables to characterize the institutions behind FMI. Firstly, we classified the lead (i.e., mandating) institution(s) of each FMl as either government, industry, or civil society (Table 2). Secondly, we recorded whether FMI decision-making structures were multi-level or monocentric. FMI were coded as multi-level if decision-making structures involved multiple jurisdictional levels (i.e., district, provincial, national, international), multiple functional sectors (i.e. agriculture, forestry, environment, public works), or multiple societal sectors (i.e. government, industry, civil society). Most FMI coded as multi-level had several of these characteristics. Although somewhat crude, this measure was most practical for our purposes, as there is no agreed-upon framework for evaluating governance properties such as polycentricity, adaptivity and multilevel character (Hooghe and Marks 2003; Huitema et al. 2009).

Table 2. FMI lead institution and decision-making structure in Riau, Indonesia (full membership list in Supplementary Table B)

\begin{tabular}{lll}
\hline Lead institution sector $I$ & Monocentric & Multilevel* $^{*}$ \\
Decision-making structure &
\end{tabular}

\begin{tabular}{lcr}
\hline Government & 23 & 15 \\
\hline Industry & 6 & 7 \\
\hline Civil society & 5 & 4 \\
\hline
\end{tabular}

* Involving multiple jurisdictional levels, functional sectors or societal sectors

177

178

179

180

181

182

183

184

185

186

187

188

189

190

191

192

193

194

195

\subsection{Method of analysis}

We used descriptive statistics to present the diversity of FMI, and non-parametric statistical tests to analyze relationships among variables describing FMI design (Table 1) and FMI institutional characteristics (Table 2). Nonparametric tests were most suitable due to the relatively small size of the dataset and the uneven distribution of observations among the variables. We used Fisher's exact test to evaluate the relatedness of categorical variables (e.g. the relatedness of our targeting variables with sector), and examined adjusted residuals using the Bonferroni correction to determine which categories were significantly related to sector. Finally, we used Kruskal-Wallis $\mathrm{H}$ tests for relationships between variables describing FMI institutional characteristics and FMI design, and the geographic scale at which FMI were intended to apply. All statistical analyses were conducted in SPSS 22.0.

\section{Results}

\subsection{Design of Fire Management Interventions}

We identified a total of $60 \mathrm{FMI}$ which addressed fire in Riau Province. FMI strategies were diverse, as captured by our four broad strategic categories (Figure 2; Table 3). They were dominated by regulation and enforcement-based strategies $(68 \%)$, almost all of which sought to 
restrict and deter fire use. Technical solutions were the second most common strategy (55\%), followed by incentive-based strategies (38\%) and reform (35\%). Importantly, most FMl employed a mix of strategies (58\%, Figure 2). Almost all FMI (92\%) included some aspect of fire prevention (e.g., canal blocking to reflood peatlands). Many (70\%) took a responsive approach to fire mitigation (e.g., fire fighting), and the majority of FMI included measures to both prevent and fight fires $(62 \%)$.

Of incentive-based FMI, a larger number than expected (50\%) employed elements of conditionality. However, the majority disbursed benefits based on the completion of an "input" action expected to reduce fire occurrence, such as the use of prescribed fire-free land-clearing methods (67\%). The remaining $42 \%$ of FMI using conditional incentives disbursed benefits based on the occurrence of a desired environmental result, such as haze severity falling below a specified threshold or a year passing without fire events ( $21 \%$ of incentive-based FMI). A small number of FMI used "new economic policy instruments", primarily eco-labelling schemes.

Nearly half of FMI were government-led interventions, although the dataset contained FMI from relatively diverse sectors, including a recent wave of industry-led FMI ( $77 \%$ of industry-led FMI appeared since 2013) (Table 3; Supplementary Table B). Nearly half of FMI (43\%) were characterized as "multi-level". There was no significant relationship between multi-level decision making and sector.

Over half of FMI (63\%) distinguished between interventions on peat versus mineral soils, and around one third of FMI focused exclusively on peat soils (33\%). Most FMI (>90\%) treated landholders differently based on whether they were "smallholders" or "businesses", but did not distinguish additional categories, and inconsistently specified the definitions used to classify landholder types. Only $12 \%$ of FMI targeted high-risk time periods.

224 presented by type of FMI strategy and lead sector (definitions in Table 1). 


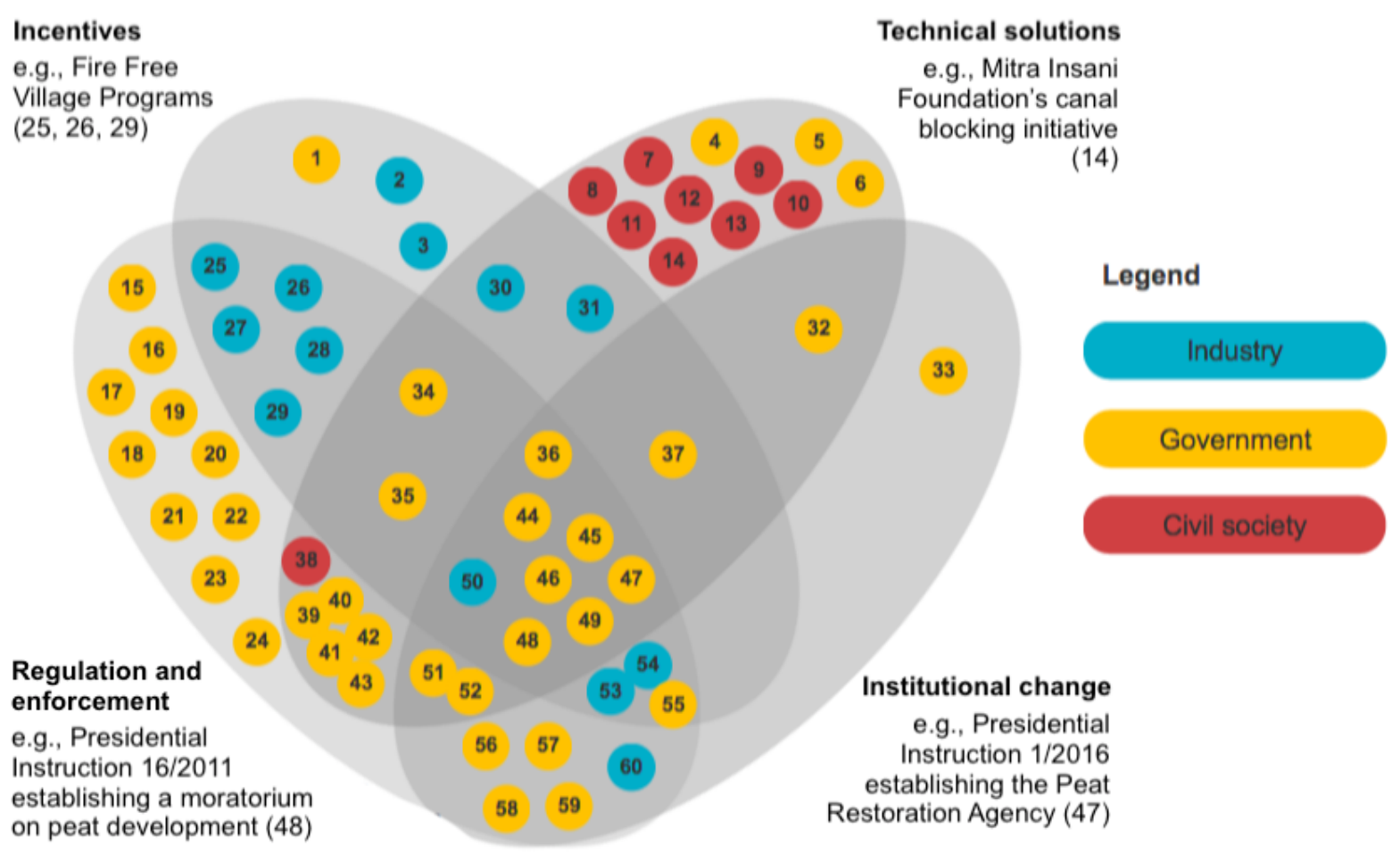

1. Indonesia-Malaysia Collaboration in Rokan Hilir

2. Integrated Forestry and Farming System Project

3. Minamas/Sime Darby fire response program

4. UNDP canal blocking

5. Indofire System

6. Southeast Asia Fire Danger Rating System

7. Perkumpulan Elang canal blocking and peat re-wetting

8. Seruni gender-based community empowerment

9. Eyes on the Forest hotspot monitoring and investigation

10. PM. Haze peatland restoration

11. Wetlands International peatland mapping

12. Greenpeace research and investigation

13. World Resources Institute research and investigation

14. Mitra Insani Foundation canal blocking

15. ASEAN ATHP Guidelines 2004

16. ASEAN ATHP Guidelines 2003

17. Government Regulation $71 / 2014$

18. Ministry of Agriculture Regulation 11/Permentan/OT.140/3/2015

19. Ministry of Agriculture Regulation 14/Permentan/PL.110/2/2009

20. Ministry of Agriculture Regulation 26/Permentan/OT.140/2/2007

21. Ministry of Agriculture Regulation 98/2013

22. Ministry of Environment Instruction S.494MENLHKPHPL2015

23. Ministry of Environment Regulation $7 / 2014$

24. Riau Provincial Regulation $8 / 2014$

25. APRIL Group Fire Free Village program

26. Asian Agri Fire Free Village program

27. Asosiasi Amanah
31. Riau Ecosystem Restoration Project

32. Indonesian National Board for Disaster Management Rapid Response Brigade

33. ASEAN Panel of Experts

34. Ministry of Forestry Regulation P.12/MenhutII/2009

35. SEApeat project

36. ASEAN Agreement on Transboundary Haze Pollution

37. Perdes $7 / 2009$ Sepahat/Bengkalis

38. Jikalahari hotspot monitoring, watchdog activities

39. Government Regulation $57 / 2016$

40. Government Regulation 45/2004

41. Presidential Instruction $10 / 2011$

42. Presidential Instruction $6 / 2013$

43. Presidential Instruction $8 / 2015$

44. ASEAN Peatland Forests Project

45. Fire Care Communities

46. Ministry of Agriculture Regulation 47/Permentan/OT.140/4/2014

47. Presidential Instruction $1 / 2016$

48. Presidential Instruction $16 / 2011$

49. Riau Governor Regulation 5/2015

50. Indonesian Palm Oil Pledge

51. Directorate General of Forest Protection and Nature Conservation 21/KTPS/DJ-IV/2002

52. Presidential Instruction $11 / 2015$

53. RSPO 2005

54. RSPO principles and criteria 2007

55. Government Regulation 4/2001

56. Governor Regulation 11/2014 
28. FSC deforestation monitoring

29. Musim Mas Fire Free Village program

30. Giam Siak Kecil Bukit Batu Biosphere Reserve
57. Minister of Agriculture 19/Permentan/OT.140/3/2011

58. Ministry of Environment Regulation 10/2010

59. REDD+ Management Agency auditing program

60. RSPO principles and criteria 2013

\subsection{Differences in FMI design across institutional types}

As we anticipated, design differed significantly between FMI from government, industry, and civil society. For example, different sectors employed distinct types of intervention strategies: sector was significantly associated with use of regulation and enforcement, incentives, technical solutions, and reform ( $p=0.000,0.000,0.001$, and 0.026 , respectively, $a=0.05$ ). Specifically, as expected, government-led FMI were associated with the use of regulatory or enforcement-based strategies $(p=0.004, a=0.008)$, and civil society-led FMI with their absence $(p=0.000, a=0.008)$.

As predicted, industry-led FMI were associated with the use of incentives $(p=0.000, a=0.008)$, while civil society-led FMI were associated with technical interventions $(p=0.004, a=0.008)$ (Figure 2). There were no significant relationships between FMI design and whether FMI decision making was multi-level.

Among FMI that used incentives, the use of conditionality was significantly associated with sector $(p=0.000, a=0.05)$. Specifically, government-led FMI were associated with the use of unconditional incentives $(p=0.002, a=0.008)$, and industry-led FMI with the use of conditional incentives $(p=0.000, a=0.008)$.

The use of eco-label schemes to verify sustainable practices was also significantly associated with sector $(p=0.000, a=0.05)$. Specifically, their use was associated with industry-led FMI $(p=0.000, a=0.008)$, and they were absent from government-led FMI ( $p=0.002, a=0.008)$. The relationships between FMI sector and FMI design variables are summarized in Table 3.

The use of targeting by FMI was low overall, as hypothesized, and largely did not vary significantly across institutional types. Targeting to peat soils and high-risk time periods were not significantly related to sector. The exception was targeting among landholders, which was significantly associated with sector $(p=0.002, a=0.05)$. Specifically, government-led $F M I$ tended to treat landholders as a uniform group (54\%), or distinguish only between "smallholders" and "businesses" (42\%) ( $p=0.001, a=0.005)$. In contrast, industry-led FMl always targeted smallholders and businesses separately $(p=0.003$, $a=0.005)$. FMI that used eco-labelling were the most nuanced, with distinct rules and programs for "businesses", "independent smallholders", and "schemed smallholders" (i.e. smallholders operating within a cooperative system within large agricultural concessions (Jelsma and Schoneveld 2017).

There were significant relationships between sector and the geographic scale on which FMI were designed to operate $(p=0.00)$ : notably, FMI led by civil society were exclusively district-level (Table 3). Incentive-based intervention strategies were also significantly associated with 
geographic scale $(p=0.00)$. Specifically, the use of incentives was associated with smaller geographic scales, with $54 \%$ of incentive-based FMI operating at the district level, and incentives triggered by results operating exclusively at the district level. That said, eco-labelling schemes were notably designed to operate on an international scale. There were no significant relationships between geographic scale and FMI targeting by soil type, landholder type or time period.

Table 3. Relationships between FMI design and lead sector (Percent by sector; asterisks indicate significant relationships, $p<0.05$; $\square$ totals equal $>100 \%$ because each FMI can fit into $>1$ category)

\begin{tabular}{|c|c|c|c|c|}
\hline & $\begin{array}{l}\text { Governme } \\
\mathrm{nt} \\
\mathrm{n}(\%)\end{array}$ & $\begin{array}{l}\text { Industry } \\
\mathrm{n}(\%)\end{array}$ & $\begin{array}{l}\text { Civil society } \\
\text { n (\%) }\end{array}$ & Total n (\%) \\
\hline \multicolumn{5}{|l|}{ Type of intervention strategy ${ }^{*} \square$} \\
\hline Regulation and enforcement & $31(82)$ & $9(69)$ & $1(11)$ & $41(68)$ \\
\hline Technical solutions & $21(55)$ & $3(23)$ & $9(100)$ & $33(55)$ \\
\hline Reform & $17(45)$ & $4(31)$ & 0 & $21(35)$ \\
\hline Incentives & $12(32)$ & 12(92) & 0 & $24(40)$ \\
\hline Use of conditionality* & $3(8)$ & $9(69)$ & 0 & $12(20)$ \\
\hline Results-based & $2(5)$ & $3(13)$ & - & $5(8)$ \\
\hline Input-based & $2(5)$ & $6(46)$ & - & $8(13)$ \\
\hline Use of eco-labels* & 0 & $5(39)$ & 0 & $5(8)$ \\
\hline \multicolumn{5}{|l|}{ Geographic scale* } \\
\hline District & $6(16)$ & $8(62)$ & $9(100)$ & $23(38)$ \\
\hline Provincial & $4(11)$ & 0 & 0 & $4(7)$ \\
\hline National & $23(62)$ & 0 & 0 & $23(38)$ \\
\hline International & $5(13)$ & $5(39)$ & 0 & $10(17)$ \\
\hline \multicolumn{5}{|l|}{ Approach $\square$} \\
\hline Fire prevention & $34(89)$ & $13(100)$ & $8(89)$ & $55(92)$ \\
\hline Fire response & $31(82)$ & $7(54)$ & $4(44)$ & $42(70)$ \\
\hline Targeting & & & & \\
\hline
\end{tabular}


273

274

275

\begin{tabular}{|l|l|l|l|l|}
\hline Target peat soils & $23(61)$ & $8(62)$ & $7(78)$ & $38(63)$ \\
\hline $\begin{array}{c}\text { Differentiate } \geq 2 \text { landholder } \\
\text { groups* }\end{array}$ & $12(32)$ & $12(92)$ & $3(33)$ & $27(45)$ \\
\hline Target high-risk time periods & $6(16)$ & 0 & $1(11)$ & $7(12)$ \\
\hline
\end{tabular}

\section{Discussion}

\subsection{FMI employed diverse types of intervention strategies}

While FMI employed strikingly diverse intervention strategies (Figure 2), a large proportion nonetheless focused on regulation and enforcement. Many of these FMI overlapped in scope, or even conflicted with other regulations (e.g., Ardiansyah et al. 2015), perhaps reflecting a "disjointed incrementalism" in the government's response to fire (see Lindblom 1979). There is evidence from both the media and the scientific literature that environmental regulations in Indonesia have historically underperformed, due to low state capacity and political accountability (e.g., McCarthy and Zen 2009; Tacconi 2016; Varkkey 2013; Nesadurai 2018). Given this evidence, our finding that regulation was a common government response to peat fire, but largely lacked appropriate targeting among landholders, suggests that many FMI are likely to face implementation challenges (e.g., Thung et al. 2019).

Interventions involving institutional reform were less common among FMI, despite the important role that institutional dysfunction has played in the peat fire problem (see Purnomo et al. 2017). For example, government agencies budgets are often tied to traditional firefighting FMI that no longer reflects best practices (Miettinen et al. 2016). This result indicates a key area in which FMI design can be improved, as does our finding that conditionality of incentives is lacking.

In contrast, while commentators on Indonesia's peat fires have long criticized a perceived lack of emphasis on fire prevention (e.g., CIFOR 2015; Purnomo et al. 2017), we found that most FMI adopted preventative approaches. These preventative FMI addressed the drivers of fire through attempts such as changing burning behavior and reducing land flammability through peatland reflooding (see Supplementary Table B). It is possible that this observed neglect has been rectified in recent years, or that fire prevention has been neglected during FMI implementation rather than in FMI design. Importantly, this shows an existing policy base from which to work.

\subsection{Intervention design differs among government, industry and civil society}

Government, industry and civil society took different approaches to FMI design. They differed significantly in terms of the types of intervention strategies they used, notably the use of incentives, and the forms of targeting they employed (Table 3). Despite these tendencies, FMI from all sectors tended to employ multiple intervention strategies and mixes were more common than single strategy approaches (Figure 2). Contrary to our expectations, our findings indicated no significant design differences between multi-level and monocentric FMI (Table 3). 
The results show that government FMI continued to be primarily based on regulation and enforcement $(82 \%)$, but were also engaged in incentive-based strategies $(32 \%)$. This reflects the increasing use of market-based tools in environmental policy by governments over the past three decades (Stavins 2003; Jordan et al. 2005; McCarthy and Zen 2009). Similarly, recent work has highlighted that many contemporary market-based environmental initiatives rely on government support and coordination (Vatn 2015). Incentives were, nevertheless, strongly associated with industry FMI, many of which have appeared in the past decade (69\% initiated since 2012). Further, where incentives were used, industry FMI were associated with the conditional disbursement of incentives, while government-led incentive schemes tended to be unconditional. This difference is particularly interesting given recent criticisms of incentive schemes that lack conditionality (e.g., Birdsall et al. 2011) and the rarity of conditional disbursement in their design (Wunder et al. 2018).

Another notable design difference among sectors involved the use of landholder targeting. Industry FMI employed significantly more nuanced landholder targeting than other sectors, frequently employing basic distinctions in landholders size, and occasionally distinguishing "independent" from "schemed" landholders. Once again, government FMl represented the opposite extreme, often treating landholders uniformly, irrespective of basic distinctions in size, types of ownership and degree of absenteeism. This finding is likely due to the fact that many industry FMI operate at the district scale allowing greater local nuance, and were led by companies with potentially strong incentives to establish fire mitigation measures with their neighbours. Indeed, industry FMI focused primarily on changing the behaviors of smallholder farmers.

These differences provide a starting point for analysing and comparing FMI performance across sectors and different design configurations (Table 1). There is also scope to test whether, as suggested in the literature, the design variables identified in Table 1 are determinants of particular social and environmental outcomes.

Moreover, our data suggests the need to further explore interactions among FMI from different sectors. For example, certain government interventions (some of which are too recent to feature in our dataset) have scaled up or adapted FMI designs pioneered by industry. This includes the Government of Indonesia's mandatory Indonesian Sustainable Palm Oil (ISPO) standard, which is a clear adaptation of the industry-led Roundtable on Sustainable Palm Oil (RSPO) standard's eco-label model (Hospes 2014). The Government of Indonesia also reportedly plans to implement the "fire free village" model developed by industry in over 700 villages across the country (Sloan et al. 2017). The "fire free village" and eco-label models were notable in our dataset for their high levels of targeting and use of conditional incentives, although both operate at limited scales. Studies of polycentric and multi-level governance systems have identified a trade-off between the nuance and policy fit that can be achieved by "messy" governance systems and the scaling and coordination that monocentric government offers (Ostrom et al. 1961). Case studies of municipal service provision, irrigation systems, and international climate governance suggest that, while multilevel and non-state interventions are often more creative, state involvement may be required for coordination at larger spatial scales (Ostrom et al. 1961; Huitema et al. 2009; Meinzen-Dick 
1997; Meinzen-Dick 2007; Bernstein and Hoffman 2018). Whether this type of policy learning is occurring in the case of Indonesia's peat fires will determine the implications of our findings. In addition, since industry FMI have tended to focus on changing smallholder behavior (with notable exceptions such as the short-lived Indonesian Palm Oil Pledge (IPOP)), scholars should monitor whether government adoption of industry intervention models serves to perpetuate blame narratives that overemphasize the culpability of smallholders (e.g., Forsyth 2014). Similarly, scholars should monitor whether complementary interventions that capture additional land users (e.g., medium sized enterprises) are enacted.

\subsection{Fire Management Interventions were largely untargeted}

As FMI promulgate rapidly, supported by development and private funds deployed after the disastrous 2015 fires, there is a need to evaluate the extent to which FMI have incorporated existing design recommendations. In particular, despite the importance of targeting to shaping outcomes (Table 1), our results showed that targeting high-risk soil types, actors and time periods was rare among the interventions in our dataset.

The most common type of targeting was based on soil type, and most FMI (63\%) targeted peat soil as distinct from mineral soil. This is important because of peat soil's specific implications for fire, haze and greenhouse gas emissions, and because of the unique biophysical challenges to fire prevention and fire fighting on peat soil (Hameiri and Jones 2017; Turetsky et al. 2014). Several prominent FMI failed to target peat soil, including the 2015 national ban on all fire use, regardless of soil type. This has limited the land use options of small-scale traditional farmers operating on mineral soil with comparatively low risk of fire escape (Thung et al, 2019; Jelmsa et al. 2017).

Among FMI that targeted landholders, few distinguished among landholder types (45\% differentiated 2 or more landholder types). When they did, distinctions were almost always limited to a coarse distinction between "smallholders" and "businesses". There is considerable scope to make this landholder targeting more reflective of land use management on-the-ground; there are at least seven distinct smallholder categories within Riau, ranging from small-scale farmers without tenure to wealthy absentee investors to medium-sized enterprises (Jelsma et al. 2017). Even FMI with the most nuanced approaches to landholder targeting did not differentiate landholders by the size of their landholding (beyond the distinction between "smallholders" and "businesses") or degree of absenteeism. Yet these different types of landholders have distinct motivations for using fire, different levels of access to alternative land-clearing techniques, and different levels of capacity to manage and fight fires (Dennis et al. 2005, Jelsma and Schoneveld 2016; Jelsma et al. 2017). Moreover, they have distinct and often conflicting perspectives on the benefits of using fire, the burdens that result from escaped peatland fires, and the effectiveness of different solutions (Carmenta et al. 2017). Failure to account for these distinctions is likely to undermine FMI performance.

Finally, FMI rarely (20\%) targeted the high-risk time periods most associated with escaped fire such as dry seasons, ENSO years, or hot or windy times of day. Yet, this temporal targeting is 
used around the world to reduce the likelihood of wildfires while enabling low-risk forms of fire use, including in Malaysia, Brazil, and Australia (Wong et al. 2010; Monzón-Alvarado et al. 2014; Taufik et al. 2018). Temporal targeting can also improve the equity outcomes of FMI by limiting restrictions on fire use among small-scale farmers who lack access to other land clearing options (Kull 2004; Carmenta et al. 2018).

403

404

Despite the ban on fire use in land management, there is some qualitative evidence that FMI targeting has tended to improve over time. For example, in 2009, the industry-led RSPO standard began to distinguish independent smallholders from schemed smallholders; the government-led ISPO standard followed suit in 2015. In 2016, the Government of Indonesia established the Peatland Restoration Agency which focuses on peatland restoration as part of its fire management efforts. The ASEAN "zero burn" guidelines for land clearing, which are often referenced by other FMI, introduced new guidelines in 2004 to allow for the managed use of fire by specific actors in specific geographic areas and time periods (ASEAN 2004).

\section{Conclusion}

As environmental governance arenas become increasingly diverse and "messy", there is an urgent need to describe and compare interventions. Mapping out the landscape (e.g., Figure 2) allows practitioners to think about "where" their interventions fall in relation to others, including others in their sector. Indeed, while anyone working on Indonesia's peat fire challenge will be familiar with some of these interventions, the diversity of FMI highlighted in this study is rarely acknowledged. Descriptive work can support policy learning by helping practitioners and emerging FMI consider possible gaps in their intervention design. For example, we highlight gaps associated with the targeting of different stakeholder types and fire risk periods, and the use of conditionality within incentive schemes-design attributes highlighted in the literature as relevant to performance.

Drawing on our documentary work, we demonstrate a method for looking at the relationships between institutional characteristics, intervention design, and--ultimately--social and environmental outcomes. This paper contributes by characterizing the institutional characteristics of fire management interventions in Indonesia, and identifying differences in design between institutional types that the literature suggests are relevant to outcomes. Future research should examine whether the differences we observed translate into differences in outcomes, and under what conditions. In particular, there is scope to explore how different strategies and levels of targeting perform, especially when it comes to the challenge of balancing nuanced intervention design with scalability.

More research is also needed on the patterns of interaction between $\mathrm{FMI}$, and between interventions responding to other complex socio-ecological problems. Weighting interventions by factors such as market footprint, legal force and political power would allow future research to better examine how diverse interventions fit together as a governance system (Morrison 2017). Given the diversity of FMI documented in this paper, future research should evaluate whether Indonesia's peat fire governance system exhibits polycentric characteristics such as policy learning and mutual adjustment (McGinnis 2016). 
443 Our results underscore the importance of developing and monitoring comprehensive databases of 444 governance activities addressing complex socio-ecological problems (e.g., Jerrells and Ostrom 445 1995; IFRI 2018; Simonet et al. 2018; LFPFN 2018). This study's categorizations can inform the 446 future development of such datasets, with the ultimate goal of identifying relationships between 447 institutional characteristics, intervention design, and outcomes. By constructing a more complete 448 understanding of environmental governance initiatives addressing tropical peat fires and other 449 complex environmental challenges, we can work towards a better understanding of how best to 450 govern them in the future. 


\section{Acknowledgements}

452 Thank you to Ramadhani Achdiawan, Aiora Zabala, Saut Sagala, Made Ali, Shita Pina Saphira, 453 Arief Wijaya, Dewi Tresya, Herry Purnomo, Bradford Sanders, Mubariq Ahmad. This research 454 was made possible under the support from the UK Department for International Development 455 (Dfid) project to the Centre for International Forestry Research project on the Political Economy of 456 Fire and Haze in Indonesia (No 203034) and the Frank Jackson Foundation.

457

$458 \quad$ Competing interests statement

459 Declarations of interest: none

460

461 
Supplementary Table A: List of experts consulted

\begin{tabular}{|l|l|}
\hline Institution & Interview date \\
\hline World Resource Institute Indonesia & February 1, 2017 \\
\hline APRIL Group & February 3, 2017 \\
\hline $\begin{array}{l}\text { Institut Pertanian Bogor, World Bank, and } \\
\text { REDD+ Task Force }\end{array}$ & February 14, 2017 \\
\hline Jikalahari & May 2, 2017 \\
\hline
\end{tabular}

463

464

Supplementary Table B: Fire Management Interventions and their institutional groupings

\begin{tabular}{|c|c|c|}
\hline $\begin{array}{c}\text { Lead actor / } \\
\text { decision-making }\end{array}$ & Monocentric & Multilevel \\
\hline Government & $\begin{array}{l}\text { Directorate General of Forest } \\
\text { Protection and Nature } \\
\text { Conservation } 21 / \text { KTPS/DJ-IV/2002 } \\
\text { on guidelines for the establishment } \\
\text { of forest fire control brigades } \\
\text { Ministry of Agriculture Regulation } \\
\text { no. 14/Permentan/PL.110/2/2009 } \\
\text { on guidelines for the utilisation of } \\
\text { peatland areas for oil palm } \\
\text { cultivation } \\
\text { Government Regulation } 71 / 2014 \\
\text { on the protection and management } \\
\text { of peatland } \\
\text { United Nations Development } \\
\text { Program (UNDP): canal blocking in } \\
\text { peatlands (2015) } \\
\text { Ministry of Environment Instruction } \\
\text { S.494MENLHK-PHPL2015 } \\
\text { prohibiting peatland development } \\
\text { Ministry of Environment Regulation } \\
10 / 2010 \text { on the mechanisms of } \\
\text { environmental pollution and } \\
\text { damage prevention related to forest } \\
\text { and land fires } \\
\text { Governor Regulation } 11 / 2014 \text { on } \\
\text { the Forest and Land Fire Control } \\
\text { Center of Riau Province }\end{array}$ & $\begin{array}{l}\text { Indonesia-Malaysia Collaboration in } \\
\text { Rokan Hilir under the ASEAN } \\
\text { Peatland Management Project: air } \\
\text { quality monitoring and education in } \\
\text { zero-burn farming techniques (2008) } \\
\text { Fire Care Communities based on } \\
\text { Regulation of The General Director } \\
\text { Forest Protection and Natural } \\
\text { Conservation No.P. 2IV-SET2014 } \\
\text { REDD+ Management Agency: } \\
\text { auditing compliance of agroforestry } \\
\text { corporations with fire and peat } \\
\text { management rules (2014) } \\
\text { Ministry of Forestry Regulation } \\
\text { P.12/Menhut-II/2009 on forest fire } \\
\text { control } \\
\text { Presidential Instruction 16/2011 on } \\
\text { the improvement of Land and Forest } \\
\text { Fire Control } \\
\text { ASEAN Agreement on } \\
\text { Transboundary Haze Pollution } \\
\text { (2002) } \\
\text { ASEAN Peatland Forests Project: } \\
\text { institutional change, conserving } \\
\text { peatlands, and encouraging } \\
\text { sustainable management ( } 2009 \text { ) }\end{array}$ \\
\hline
\end{tabular}


Indonesian National Board for Disaster Management Rapid

Response Brigade (2009)

Government of Indonesia

Regulation 4/2001 on

environmental damage and

pollution control in relation to forest

and land fires

Government of Indonesia

Regulation 45/2004 on forest

protection

Ministry of Agriculture Regulation

no. 26/Permentan/OT.140/2/2007

on the guidelines for estate crop

licensing

Presidential Instruction 10/2011

establishing a moratorium on

developing peatlands

Presidential Instruction 6/2013

establishing a moratorium on

developing peatlands

Ministry of Agriculture Regulation

no. 47/Permentan/OT.140/4/2014

on the establishment of fire brigade and the guidelines for the

prevention and control of forest and land fires

Ministry of Environment Regulation 7/2014 on environmental loss due to pollution and environmental damages

Presidential Instruction 11/2015 on the improvement of forest and land fire control

Presidential Instruction 8/2015 establishing a moratorium on developing peatlands

Ministry of Agriculture Regulation no. 11/Permentan/OT.140/3/2015
ASEAN Panel of Experts on Fire and Haze Assessment and Coordination (2005)

SEApeat project: institutional change, fire monitoring, and incentives and education for sustainable peatland management (2011)

Southeast Asia Fire Danger Rating System project (1999)

Indofire System under the IndonesiaAustralia Forest Carbon Partnership: hotspot monitoring (2009)

Perdes 7/2009 Sepahat/Bengkalis

ASEAN Agreement on

Transboundary Haze Pollution: Guidelines for the Implementation of the ASEAN Policy on Zero Burning (2003)

ASEAN Agreement on Transboundary Haze Pollution: Guidelines for the Implementation of Controlled Burning Practices (2004) 


\begin{tabular}{|c|c|c|}
\hline & $\begin{array}{l}\text { on Indonesian Sustainable Palm } \\
\text { Oil (ISPO) } \\
\text { Presidential Instruction 1/2016 on } \\
\text { Peat Restoration Agency } \\
\text { Riau Provincial Regulation 8/2014 } \\
\text { on Environmental Management } \\
\text { and Environmental Law } \\
\text { Compliance Riau Province } \\
\text { Ministry of Agriculture Regulation } \\
\text { No. } 98 \text { of } 2013 \\
\text { Minister of Agriculture } \\
\text { No.19/Permentan/OT.140/3/2011 } \\
\text { creating the Indonesian } \\
\text { Sustainable Palm Oil certification } \\
\text { Government Regulation No. } \\
\text { 57/2016 } \\
\text { Riau Governor Regulation No. } \\
\text { 5/2015 }\end{array}$ & \\
\hline Industry & $\begin{array}{l}\text { Riau Ecosystem Restoration } \\
\text { Project (APRIL Group in } \\
\text { partnership with Flora and Fauna } \\
\text { International and Bidara): support } \\
\text { and incentives for community- } \\
\text { based conservation on the Kampar } \\
\text { Peninsula (2013) } \\
\\
\text { Integrated Forestry and Farming } \\
\text { System Project (Asia Pulp and } \\
\text { Paper in partnership with Desa } \\
\text { Makmur Peduli Api) (2016): support } \\
\text { and incentives for community- } \\
\text { based forest conservation } \\
\text { APRIL Group Fire Free Village } \\
\text { program: fire management } \\
\text { incentives and education for } \\
\text { communities (2014) } \\
\text { Asian Agri Fire Free Village } \\
\text { program: fire management } \\
\text { incentives and education for } \\
\text { communities (2016) }\end{array}$ & $\begin{array}{l}\text { Roundtable on Sustainable Palm Oil } \\
\text { (RSPO): principles and criteria } \\
\text { (2013) } \\
\text { Asosiasi Amanah: oil palm } \\
\text { smallholders collective providing } \\
\text { support for RSPO and ISPO } \\
\text { certification (2011) } \\
\text { Forest Stewardship Council (FSC): } \\
\text { deforestation monitoring (2014) } \\
\text { Indonesian Palm Oil Pledge (IPOP): } \\
\text { evaluation and audit licensing of peat } \\
\text { (2015) } \\
\text { Giam Siak Kecil Bukit Batu } \\
\text { Biosphere Reserve (Sinar Mas in } \\
\text { partnership with civil society and } \\
\text { government) (2009) } \\
\text { Roundtable on Sustainable Palm Oil } \\
\text { (RSPO): principles and criteria } \\
\text { (2007) }\end{array}$ \\
\hline
\end{tabular}




\begin{tabular}{|c|c|c|}
\hline & $\begin{array}{l}\text { Musim Mas Fire Free Village } \\
\text { program: fire management } \\
\text { incentives and education for } \\
\text { communities (2016) } \\
\text { Minamas/Sime Darby: fire } \\
\text { response and monitoring and fire } \\
\text { management education for } \\
\text { communities (2015) }\end{array}$ & $\begin{array}{l}\text { Roundtable on Sustainable Palm Oil } \\
\text { (RSPO) (2005) }\end{array}$ \\
\hline Civil society & $\begin{array}{l}\text { Wetlands International: peatland } \\
\text { mapping in consultation with } \\
\text { Deltares (2015) } \\
\text { Greenpeace: research and } \\
\text { investigation (2013) } \\
\text { Indonesian Women's Union } \\
\text { (Seruni): gender-based community } \\
\text { empowerment (2015) } \\
\text { Riau Forest Rescue Network } \\
\text { (Jikalahari): hotspot monitoring and } \\
\text { watchdog activities (2016) } \\
\text { Mitra Insani Foundation: canal } \\
\text { blocking (2012) }\end{array}$ & $\begin{array}{l}\text { World Resources Institute: research } \\
\text { and investigation (2014) } \\
\text { Eyes on the Forest: hotspot } \\
\text { monitoring and investigation (2015) } \\
\text { Perkumpulan Elang in partnership } \\
\text { with the Riau Natural Resources } \\
\text { Conservation Centre: canal blocking } \\
\text { and peat re-wetting (2016) } \\
\text { People's Movement to Stop Haze } \\
\text { Singapore (PM.Haze): peatland } \\
\text { restoration (2014) }\end{array}$ \\
\hline
\end{tabular}

\section{References:}

1. Agrawal, A. and Lemos, M.C., 2007. A greener revolution in the making?: Environmental governance in the 21st century. Environment: Science and Policy for Sustainable Development, 49(5), pp.36-45.

2. Anderson, T.L. and Leal, D.R., 1991. Free market environmentalism.

3. Ardiansyah, F., Marthen, A.A. and Amalia, N., 2015. Forest and land-use governance in a decentralized Indonesia: A legal and policy review (Vol. 132). CIFOR.

4. Barlow, J., França, F., Gardner, T.A., Hicks, C.C., Lennox, G.D., Berenguer, E., Castello, L., Economo, E.P., Ferreira, J., Guénard, B. and Leal, C.G., 2018. The future of hyperdiverse tropical ecosystems. Nature, 559(7715), p.517.

5. Bernstein, S. and Hoffmann, M., 2018. The politics of decarbonization and the catalytic impact of subnational climate experiments. Policy Sciences, 51(2), pp.189-211.

6. Birdsall, Nancy, William D. Savedoff, Ayah Mahgoub, and Katherine Vyborny. Cash on delivery: a new approach to foreign aid. CGD Books, 2012.

7. Bompard, J. M., and Guizol, P., 1999. Land management in the province of South Sumatra, Indonesia. Fanning the flames: The institutional causes of vegetation fires. Forest Fire Prevention and Control Project, European Commission, Jakarta, Indonesia. 
484

485

486

487

488

489

490

491

492

493

494

495

496

497

498

499

500

501

502

503

504

505

506

507

508

509

510

511

512

513

514

515

516

517

518

519

520

521

522

523

524

525

526

527
8. Carmenta, R., Vermeylen, S., Parry, L. and Barlow, J., 2013. Shifting cultivation and fire policy: insights from the Brazilian Amazon. Human Ecology, 41(4), pp.603-614.

9. Carmenta, R., Zabala, A., Daeli, W. and Phelps, J., 2017. Perceptions across scales of governance and the Indonesian peatland fires. Global Environmental Change, 46, pp.5059.

10. Carmenta, R., Coudel, E. and Steward, A.M., 2018. Forbidden fire: Does criminalising fire hinder conservation efforts in swidden landscapes of the Brazilian Amazon?. The Geographical Journal.

11. Cash, D., Adger, W.N., Berkes, F., Garden, P., Lebel, L., Olsson, P., Pritchard, L. and Young, O., 2006. Scale and cross-scale dynamics: governance and information in a multilevel world. Ecology and society, 11(2).

12. Cashore, B.W., Auld, G. and Newsom, D., 2004. Governing through markets: Forest certification and the emergence of non-state authority. Yale University Press.

13. Cattau, M.E., Harrison, M.E., Shinyo, I., Tungau, S., Uriarte, M. and DeFries, R., 2016. Sources of anthropogenic fire ignitions on the peat-swamp landscape in Kalimantan, Indonesia. Global environmental change, 39, pp.205-219.

14. Ceruti, M., 2016. APRIL Ecosystem Restoration Project: A sustainable model for Indonesian peatlands?.

15. Chokkalingam, U., Permana, R.P., Kurniawan, I., Mannes, J., Darmawan, A., Khususyiah, N. and Susanto, R.H., 2007. Community fire use, resource change, and livelihood impacts: The downward spiral in the wetlands of southern Sumatra. Mitigation and Adaptation Strategies for Global Change, 12(1), pp.75-100.

16. Dennis, R., 1999. A review of fire projects in Indonesia, 1982-1998. Cifor.

17. Dennis, R.A., Mayer, J., Applegate, G., Chokkalingam, U., Colfer, C.J.P., Kurniawan, I., Lachowski, H., Maus, P., Permana, R.P., Ruchiat, Y. and Stolle, F., 2005. Fire, people and pixels: linking social science and remote sensing to understand underlying causes and impacts of fires in Indonesia. Human Ecology, 33(4), pp.465-504.

18. Di Gregorio, M., Fatorelli, L., Paavola, J., Locatelli, B., Pramova, E., Nurrochmat, D.R., May, P.H., Brockhaus, M., Sari, I.M. and Kusumadewi, S.D., 2019. Multi-level governance and power in climate change policy networks. Global Environmental Change, 54, pp.6477.

19. Ding, Y., Liu, Y., Liu, S., Li, Z., Tan, X., Huang, X., Zeng, G., Zhou, L. and Zheng, B., 2016. Biochar to improve soil fertility. A review. Agronomy for Sustainable Development, $36(2)$, p.36.

20. Doelle, M., Henschel, C., Smith, J., Tollefson, C. and Wellstead, A., 2012. New governance arrangements at the intersection of climate change and forest policy: institutional, political and regulatory dimensions. Public Administration, 90(1), pp.37-55.

21. Dove, M.R., 1985. The agroecological mythology of the Javanese and the political economy of Indonesia. Indonesia, (39), pp.1-36.

22. Ekadinata, S., Van Noordwijk, M., Budidarsono, S. and Dewi, S., 2013. Hot spots in Riau, haze in Singapore: the June 2013 event analyzed. ASB Policy brief, (33), p.6.

23. Food and Agriculture Organization (FAO), 2006. Fire management: voluntary guidelines. Principles and strategic actions. Fire Management Working Paper 17. Rome (also available at www.fao.org/forestry/site/35853/en). 
552

553

554

555

556

557

558

559

560

561

562

563

564

565

566

567

568

569

570
24. Forsyth, T., 2010. Panacea or paradox? Cross-sector partnerships, climate change, and development. Wiley Interdisciplinary Reviews: Climate Change, 1(5), pp.683-696.

25. Forsyth, T., 2014. Public concerns about transboundary haze: A comparison of Indonesia, Singapore, and Malaysia. Global Environmental Change, 25, pp.76-86.

26. Gaveau, D.L., Salim, M.A., Hergoualc'h, K., Locatelli, B., Sloan, S., Wooster, M., Marlier, M.E., Molidena, E., Yaen, H., DeFries, R. and Verchot, L., 2014. Major atmospheric emissions from peat fires in Southeast Asia during non-drought years: evidence from the 2013 Sumatran fires. Scientific reports, 4, p.6112.

27. Gaveau, D.L., Pirard, R., Salim, M.A., Tonoto, P., Yaen, H., Parks, S.A. and Carmenta, R., 2017. Overlapping land claims limit the use of satellites to monitor no-deforestation commitments and no-burning compliance. Conservation Letters, 10(2), pp.257-264.

28. Global Comparative Study (GCS) on REDD+. 2018. Center for International Forestry Research (CIFOR), Bogor Indonesia. URL: https://www.cifor.org/gcs/

29. Gnych, S.M., Limberg, G. and Paoli, G., 2015. Risky business: Motivating uptake and implementation of sustainability standards in the Indonesian palm oil sector. Occasional Paper 139. Bogor, Indonesia: CIFOR.

30. Hameiri, S. and Jones, L., 2015. Governing borderless threats: Non-traditional security and the politics of state transformation. Cambridge University Press.

31. Hahn, R.W. and Stavins, R.N., 1991. Incentive-based environmental regulation: A new era from an old idea. Ecology $L Q, 18$, p.1.

32. Harwell, E., 2000. Remote sensibilities: discourses of technology and the making of Indonesia's natural disaster. Development and change, 31(1), pp.307-340.

33. Hepburn, C., 2010. Environmental policy, government, and the market. Oxford Review of Economic Policy, 26(2), pp.117-136.

34. Hidayat, K.N., Glasbergen, P. and Offermans, A., 2015. Sustainability certification and palm oil smallholders' livelihood: a comparison between scheme smallholders and independent smallholders in Indonesia. International Food and Agribusiness Management Review, 18(1030-2016-83041), p.25.

35. Hooghe, L. and Marks, G., 2003. Unraveling the central state, but how? Types of multilevel governance. American Political Science Review, 97(2), pp.233-243.

36. Hospes, O., 2014. Marking the success or end of global multi-stakeholder governance? The rise of national sustainability standards in Indonesia and Brazil for palm oil and soy. Agriculture and Human Values, 31(3), pp.425-437.

37. Huijnen, V., Wooster, M.J., Kaiser, J.W., Gaveau, D.L., Flemming, J., Parrington, M., Inness, A., Murdiyarso, D., Main, B. and van Weele, M., 2016. Fire carbon emissions over maritime southeast Asia in 2015 largest since 1997. Scientific Reports, 6, p.26886.

38. Huitema, D., Mostert, E., Egas, W., Moellenkamp, S., Pahl-Wostl, C. and Yalcin, R., 2009. Adaptive water governance: assessing the institutional prescriptions of adaptive (co-) management from a governance perspective and defining a research agenda. Ecology and Society, 14(1), p.26.

39. Jelsma, I. and Schoneveld, G.C., 2016. Towards more sustainable and productive independent oil palm smallholders in Indonesia: Insights from the development of a smallholder typology (Vol. 210). CIFOR. 
40. Jelsma, I., Schoneveld, G.C., Zoomers, A. and Van Westen, A.C.M., 2017. Unpacking Indonesia's independent oil palm smallholders: An actor-disaggregated approach to identifying environmental and social performance challenges. Land Use Policy, 69, pp.281-297.

41. Jolly, W.M., Cochrane, M.A., Freeborn, P.H., Holden, Z.A., Brown, T.J., Williamson, G.J. and Bowman, D.M., 2015. Climate-induced variations in global wildfire danger from 1979 to 2013. Nature Communications, 6, p.7537.

42. International Forestry Resources and Institutions (IFRI), 2018. School for Environment and Sustainability, University of Michigan, Ann Arbor, USA [online]. Available at: http://www.ifriresearch.net/.

43. Jerrells, J. and Ostrom, E., 1995. Current developments in a relational database for biological and social science research. In IUFRO World Congress Conference, Tampere, Finland, August (pp. 8-11).

44. Jong, H., 2015. 'Government opposes zero-deforestation pledge by palm oil firms', The Jakarta Post, 29 August.

45. Jong, H., 2017. 'The Indonesian government is forcing private companies to pay for damaging its forests', The Pacific Standard, 23 August [online]. Available at: https://psmag.com/environment/indonesian-government-forcing-private-companies-to-payfor-damaging-its-forests

46. Jordan, A., Wurzel, R.K. and Zito, A., 2005. The rise of 'new' policy instruments in comparative perspective: has governance eclipsed government?. Political Studies, 53(3), pp.477-496.

47. Jordan, A.J., Huitema, D., Hildén, M., Van Asselt, H., Rayner, T.J., Schoenefeld, J.J., Tosun, J., Forster, J. and Boasson, E.L., 2015. Emergence of polycentric climate governance and its future prospects. Nature Climate Change, 5(11), p.977.

48. Koontz, T.M. and Thomas, C.W., 2006. What do we know and need to know about the environmental outcomes of collaborative management?. Public administration review, 66, pp.111-121.

49. Koplitz, S.N., Mickley, L.J., Marlier, M.E., Buonocore, J.J., Kim, P.S., Liu, T., Sulprizio, M.P., DeFries, R.S., Jacob, D.J., Schwartz, J. and Pongsiri, M., 2016. Public health impacts of the severe haze in Equatorial Asia in September-October 2015: demonstration of a new framework for informing fire management strategies to reduce downwind smoke exposure. Environmental Research Letters, 11(9), p.094023.

50. Kull, C.A., 2004. Isle of fire: the political ecology of landscape burning in Madagascar (Vol. 245). University of Chicago press.

51. Lambin, E.F., Meyfroidt, P., Rueda, X., Blackman, A., Börner, J., Cerutti, P.O., Dietsch, T., Jungmann, L., Lamarque, P., Lister, J. and Walker, N.F., 2014. Effectiveness and synergies of policy instruments for land use governance in tropical regions. Global Environmental Change, 28, pp.129-140.

52. Lindblom, C.E., 1979. Still muddling, not yet through. Public Administration Review 39:517-526.

53. Landscapes for People, Food and Nature (LPFN), 2018. EcoAgriculture Partners, Washington, DC [online]. Available at: http://peoplefoodandnature.org/ 
614

615

616

617

618

619

620

621

622

623

624

625

626

627

628

629

630

631

632

633

634

635

636

637

638

639

640

641

642

643

644

645

646

647

648

649

650

651

652

653

654

655

656

54. Lohberger, S., Stängel, M., Atwood, E.C. and Siegert, F., 2018. Spatial evaluation of Indonesia's 2015 fire-affected area and estimated carbon emissions using Sentinel-1. Global Change Biology, 24(2), pp.644-654.

55. Mathews, A.S., 2005. Power/knowledge, power/ignorance: forest fires and the state in Mexico. Human Ecology, 33(6), pp.795-820.

56. Marino, E., Ribot, J., 2012. Special issue introduction: adding insult to injury: climate change and the inequities of climate intervention. Global Environmental Change 22(2):323-328.

57. Marlier, M.E., DeFries, R.S., Kim, P.S., Koplitz, S.N., Jacob, D.J., Mickley, L.J. and Myers, S.S., 2015. Fire emissions and regional air quality impacts from fires in oil palm, timber, and logging concessions in Indonesia. Environmental Research Letters, 10(8), p.085005.

58. Martin, D. A. (2019). Linking fire and the United Nations Sustainable Development Goals. Science of the Total Environment, 662, 547-558.

59. Mayer, J., 2006. Transboundary perspectives on managing Indonesia's fires. The Journal of Environment \& Development, 15(2), pp.202-223.

60. McCarthy, J. and Zen, Z., 2010. Regulating the oil palm boom: assessing the effectiveness of environmental governance approaches to agro-industrial pollution in Indonesia. Law \& Policy, 32(1), pp.153-179.

61. McCarthy, J.F., Vel, J.A. and Afiff, S., 2012. Trajectories of land acquisition and enclosure: development schemes, virtual land grabs, and green acquisitions in Indonesia's Outer Islands. Journal of Peasant Studies, 39(2), pp.521-549.

62. McGinnis, M.D., 2016. The Ostrom Polycentricity Workshop, in: Polycentric Governance in Theory and Practice: Dimensions of Aspiration and Practical Limitations. December 14-17.

63. Meinzen-Dick, R., 1997. Farmer participation in irrigation-20 years of experience and lessons for the future. Irrigation and Drainage Systems, 11(2), pp.103-118.

64. Meinzen-Dick, R., 2007. Beyond panaceas in water institutions. Proceedings of the National Academy of Sciences, 104(39), pp.15200-15205.

65. Miettinen, J., Hooijer, A., Wang, J., Shi, C. and Liew, S.C., 2012. Peatland degradation and conversion sequences and interrelations in Sumatra. Regional Environmental Change, 12(4), pp.729-737.

66. Miettinen, J., Shi, C. and Liew, S.C., 2016. Land cover distribution in the peatlands of Peninsular Malaysia, Sumatra and Borneo in 2015 with changes since 1990. Global Ecology and Conservation, 6, pp.67-78.

67. Monzón-Alvarado, C., Waylen, P. and Keys, E., 2014. Fire management and climate variability: Challenges in designing environmental regulations. Land Use Policy, 39, pp.1221.

68. Morrison, T.H., 2017. Evolving polycentric governance of the Great Barrier Reef. Proceedings of the National Academy of Sciences, 114(15), pp.E3013-E3021.

69. Nesadurai, H.E., 2018. New constellations of social power: States and transnational private governance of palm oil sustainability in Southeast Asia. Journal of Contemporary Asia, 48(2), pp.204-229.

70. Newig, J. and Fritsch, O., 2009. Environmental governance: participatory, multi-level-and effective?. Environmental Policy and Governance, 19(3), pp.197-214. 
71. Newton, P., Nichols, E.S., Endo, W. and Peres, C.A., 2012. Consequences of actor level livelihood heterogeneity for additionality in a tropical forest payment for environmental services programme with an undifferentiated reward structure. Global Environmental Change, 22(1), pp.127-136.

72. Nurhidayah, L., 2014. Transboundary Haze Pollution in the ASEAN Region: an Assessment of the Adequacy of the Legal and Policy Framework in Indonesia (thesis).

73. Obidzinski, K. and Kusters, K., 2015. Formalizing the logging sector in Indonesia: Historical dynamics and lessons for current policy initiatives. Society \& Natural Resources, 28(5), pp.530-542.

74. Ostrom, E., 2010. Polycentric systems for coping with collective action and global environmental change. Global Environmental Change, 20(4), pp.550-557.

75. Ostrom, E., Janssen, M.A. and Anderies, J.M., 2007. Going beyond panaceas. Proceedings of the National Academy of Sciences, 104(39), pp.15176-15178.

76. Ostrom, V., Tiebout, C.M. and Warren, R., 1961. The organization of government in metropolitan areas: a theoretical inquiry. American Political Science Review, 55(4), pp.831-842.

77. Padfield, R., Drew, S., Syayuti, K., Page, S., Evers, S., Campos-Arceiz, A., Kangayatkarasu, N., Sayok, A., Hansen, S., Schouten, G. and Maulidia, M., 2016. Landscapes in transition: an analysis of sustainable policy initiatives and emerging corporate commitments in the palm oil industry. Landscape Research, 41(7), pp.744-756.

78. Paoli, G., Aurora, L., Palmer, B., Prasodjo, R., Schweithelm, J., 2015. Indonesia's evolving governance framework for palm oil: implications for a no deforestation, no peat palm oil sector. Daemeter Consulting.

79. Padt, F., Opdam, P., Polman, N., Termeer, C. (Eds.). 2014. Scale-sensitive governance of the environment. John Wiley \& Sons.

80. Pascual, U., Phelps, J., Garmendia, E., Brown, K., Corbera, E., Martin, A., GomezBaggethun, E. and Muradian, R., 2014. Social equity matters in payments for ecosystem services. Bioscience, 64(11), pp.1027-1036.

81. Persoon, G.A. and Simarmata, R., 2014. Undoing 'marginality': the islands of the Mahakam delta, East Kalimantan (Indonesia). Journal of Marine and Island Cultures, 3(2), pp.43-53.

82. Purnomo, H., Shantiko, B., Sitorus, S., Gunawan, H., Achdiawan, R., Kartodihardjo, H., \& Dewayani, A. A. (2017). Fire economy and actor network of forest and land fires in Indonesia. Forest Policy and Economics, 78, 21-31.

83. Rhodes, R.A.W., 1996. The new governance: governing without government. Political Studies, 44(4), pp.652-667.

84. Sargeant, H.J., 2001. Vegetation fires in Sumatra Indonesia. Oil palm agriculture in the wetlands of Sumatra: destruction or development? (No. D-1836). European Union Ministry of Forestry.

85. Sattler, C., Trampnau, S., Schomers, S., Meyer, C. and Matzdorf, B., 2013. Multiclassification of payments for ecosystem services: how do classification characteristics relate to overall PES success?. Ecosystem Services, 6, pp.31-45.

86. Simonet G., Agrawal A., Bénédet F., Cromberg M., de Perthuis C., Haggard D., Jansen N., Karsenty A., Liang W., Newton P., Sales A-M, Schaap B., Seyller C., Vaillant G., 2018. 
ID-RECCO, International Database on REDD+ projects and programs, linking economic, carbon and communities data, version 3.0 [online]. Available at: http://www.reddprojectsdatabase.org

87. Sloan, S., Locatelli, B., Wooster, M.J. and Gaveau, D.L., 2017. Fire activity in Borneo driven by industrial land conversion and drought during El Niño periods, 1982-2010. Global Environmental Change, 47, pp.95-109.

88. Stavins, R.N., 2003. Experience with market-based environmental policy instruments. In Handbook of environmental economics (Vol. 1, pp. 355-435).

89. Stewart, R.B., Oppenheimer, M. and Rudyk, B., 2013. A new strategy for global climate protection. Climatic change, 120(1-2), pp.1-12.

90. Stolle, F., Chomitz, K.M., Lambin, E.F. and Tomich, T.P., 2003. Land use and vegetation fires in Jambi Province, Sumatra, Indonesia. Forest Ecology and Management, 179(1-3), pp.277-292.

91. Tacconi, L., 2016. Preventing fires and haze in Southeast Asia. Nature Climate Change, $6(7)$, p.640.

92. Tacconi, L. and Ruchiat, Y., 2006. Livelihoods, fire and policy in eastern Indonesia. Singapore Journal of Tropical Geography, 27(1), pp.67-81.

93. Tan, A.K.J., 2005. The ASEAN agreement on transboundary haze pollution: Prospects for compliance and effectiveness in post-Suharto Indonesia. New York University Environmental Law Journal, 13, p.647.

94. Tan-Soo, J.-S., \& Pattanayak, S. K. (2019). Seeking natural capital projects: Forest fires, haze, and early-life exposure in Indonesia. Proceedings of the National Academy of Sciences, 116(12), 5239 LP-5245.

95. Taufik, M., Setiawan, B.I. and Van Lanen, H.A., 2018. Increased fire hazard in humanmodified wetlands in Southeast Asia. Ambio, pp.1-11.

96. Termeer, C.J., Dewulf, A. and Van Lieshout, M., 2010. Disentangling scale approaches in governance research: comparing monocentric, multilevel, and adaptive governance. Ecology and Society, 15(4), pp.29-29.

97. Thung, P.H., 2018. A Case Study on the Persistence of Swidden Agriculture in the Context of Post-2015 Anti-Haze Regulation in West-Kalimantan. Human Ecology, 46(2), pp.197205.

98. Toomey, A.H., Knight, A.T. and Barlow, J., 2017. Navigating the space between research and implementation in conservation. Conservation Letters, 10(5), pp.619-625.

99. Turetsky, M.R., Benscoter, B., Page, S., Rein, G., Van Der Werf, G.R. and Watts, A., 2015. Global vulnerability of peatlands to fire and carbon loss. Nature Geoscience, $8(1)$, p.11.

100. Van Der Werf, G., 2015. Updates vol. 2015 [online]. Global Fire Data. Available at: http://www.globalfiredata.org/updates.html (Accessed 07.01.2018).

101. Varkkey, H., 2013. Oil palm plantations and transboundary haze: patronage networks and land licensing in Indonesia's peatlands. Wetlands, 33(4), pp.679-690.

102. Vatn, A., 2015. Markets in environmental governance. From theory to practice. Ecological Economics, 117, pp.225-233.

103. Vayda, A.P., 2010. Explaining Indonesian forest fires: Both ends of the firestick. In Human Ecology (pp. 17-35). Springer, Boston, MA. 
104. Veríssimo, D. and Wan, A.K., 2018. Characterizing efforts to reduce consumer demand for wildlife products. Conservation Biology.

105. Whitehouse, A.E. and Mulyana, A.A., 2004. Coal fires in Indonesia. International Journal of Coal Geology, 59(1-2), pp.91-97.

106. Wijedasa, L.S., Jauhiainen, J., Könönen, M., Lampela, M., Vasander, H., Leblanc, M.C., Evers, S., Smith, T.E., Yule, C.M., Varkkey, H. and Lupascu, M., 2017. Denial of long-term issues with agriculture on tropical peatlands will have devastating consequences. Global Change Biology, 23(3), pp.977-982.

107. Wong, J.O.Y.C.E., Marshall, Q., Jay, A. and Boer, R., 2010. The Use of a Seasonal Fire Early Warning Tool for Managing Peat Fires in Indonesia. International Research Institute For Climate And Society. Bogor Agricultural University, Bogor, Indonesia.

108. Wunder, S., 2005. Payments for Environmental Services: Some Nuts and Bolts. Occasional Paper No. 42. CIFOR, Bogor.

109. Wunder, S., Brouwer, R., Engel, S., Ezzine-de-Blas, D., Muradian, R., Pascual, U. and Pinto, R., 2018. From principles to practice in paying for nature's services. Nature Sustainability, 1(3), p.145.

110. Wunscher, T., Engel, S. and Wunder, S., 2006. Payments for environmental services in Costa Rica: increasing efficiency through spatial differentiation. Quarterly Journal of International Agriculture, 45(4), pp.319-338.

111. Wünscher, T., Engel, S. and Wunder, S., 2008. Spatial targeting of payments for environmental services: a tool for boosting conservation benefits. Ecological Economics, 65(4), pp.822-833.

112. Young, O.R., 2002. The institutional dimensions of environmental change: fit, interplay, and scale. MIT Press, Cambridge, MA.

113. Yule, C.M., 2010. Loss of biodiversity and ecosystem functioning in Indo-Malayan peat swamp forests. Biodiversity and Conservation, 19(2), pp.393-409.

114. Zabel, A. and Engel, S., 2010. Performance payments: A new strategy to conserve large carnivores in the tropics?. Ecological Economics, 70(2), pp.405-412. 
Supplementary Table A: List of experts consulted

\begin{tabular}{|l|l|}
\hline Institution & Interview date \\
\hline World Resource Institute Indonesia & February 1, 2017 \\
\hline APRIL Group & February 3, 2017 \\
\hline Institut Pertanian Bogor, World Bank, and REDD+ Task Force & February 14, 2017 \\
\hline Jikalahari & May 2, 2017 \\
\hline
\end{tabular}

\section{Supplementary Table B: Fire management interventions and their institutional} characteristics

\begin{tabular}{|c|c|c|}
\hline $\begin{array}{l}\text { Lead actor / } \\
\text { decision- } \\
\text { making }\end{array}$ & Monocentric & Multilevel \\
\hline Government & $\begin{array}{l}\text { Directorate General of Forest Protection and } \\
\text { Nature Conservation } 21 / \text { KTPS/DJ-IV/2002 on } \\
\text { guidelines for the establishment of forest fire } \\
\text { control brigades } \\
\text { Ministry of Agriculture Regulation no. } \\
14 / \text { Permentan/PL.110/2/2009 on guidelines } \\
\text { for the utilisation of peatland areas for oil } \\
\text { palm cultivation } \\
\text { Government Regulation } 71 / 2014 \text { on the } \\
\text { protection and management of peatland } \\
\text { United Nations Development Program } \\
\text { (UNDP): canal blocking in peatlands (2015) } \\
\text { Ministry of Environment Instruction } \\
\text { S.494MENLHK-PHPL2015 prohibiting } \\
\text { peatland development } \\
\text { Ministry of Environment Regulation } 10 / 2010 \\
\text { on the mechanisms of environmental } \\
\text { pollution and damage prevention related to } \\
\text { forest and land fires } \\
\text { Governor Regulation } 11 / 2014 \text { on the Forest } \\
\text { and Land Fire Control Center of Riau } \\
\text { Province } \\
\text { Indonesian National Board for Disaster } \\
\text { Management Rapid Response Brigade } \\
\text { (2009) }\end{array}$ & $\begin{array}{l}\text { Indonesia-Malaysia } \\
\text { Collaboration in Rokan Hilir } \\
\text { under the ASEAN Peatland } \\
\text { Management Project: air } \\
\text { quality monitoring and } \\
\text { education in zero-burn } \\
\text { farming techniques (2008) } \\
\text { Fire Care Communities } \\
\text { based on Regulation of The } \\
\text { General Director Forest } \\
\text { Protection and Natural } \\
\text { Conservation No.P. 2IV- } \\
\text { SET2014 } \\
\text { REDD+ Management } \\
\text { Agency: auditing compliance } \\
\text { of agroforestry corporations } \\
\text { with fire and peat } \\
\text { management rules (2014) } \\
\text { Ministry of Forestry } \\
\text { Regulation P.12/Menhut- } \\
\text { II/2009 on forest fire control } \\
\\
\text { Presidential Instruction } \\
16 / 2011 \text { on the improvement } \\
\text { of Land and Forest Fire } \\
\text { Control }\end{array}$ \\
\hline
\end{tabular}




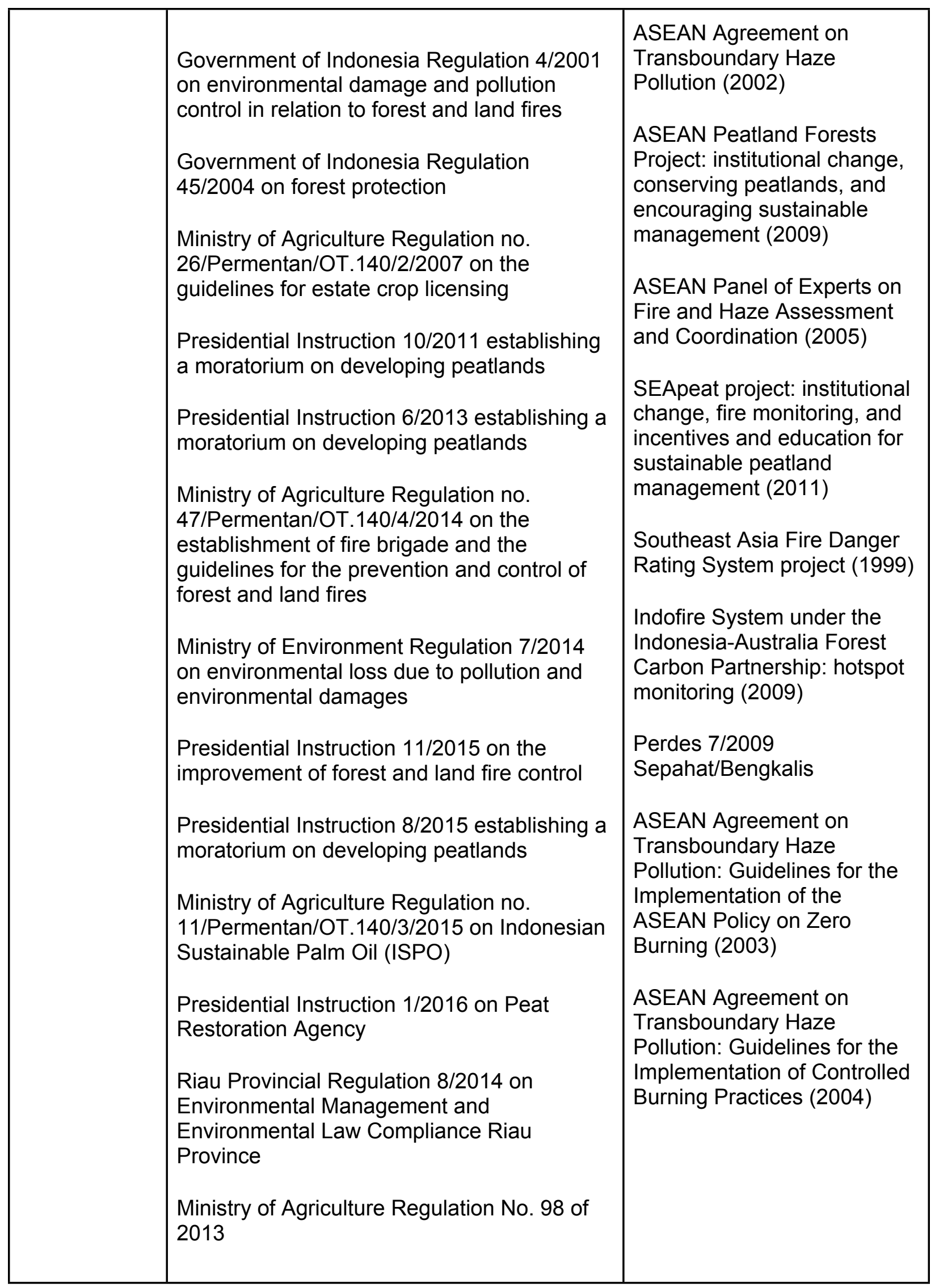




\begin{tabular}{|c|c|c|}
\hline & $\begin{array}{l}\text { Minister of Agriculture } \\
\text { No.19/Permentan/OT.140/3/2011 creating } \\
\text { the Indonesian Sustainable Palm Oil } \\
\text { certification } \\
\text { Government Regulation No. } 57 / 2016 \\
\text { Riau Governor Regulation No. 5/2015 }\end{array}$ & \\
\hline Industry & $\begin{array}{l}\text { Riau Ecosystem Restoration Project (APRIL } \\
\text { Group in partnership with Flora and Fauna } \\
\text { International and Bidara): support and } \\
\text { incentives for community-based conservation } \\
\text { on the Kampar Peninsula (2013) } \\
\text { Integrated Forestry and Farming System } \\
\text { Project (Asia Pulp and Paper in partnership } \\
\text { with Desa Makmur Peduli Api) (2016): } \\
\text { support and incentives for community-based } \\
\text { forest conservation } \\
\text { APRIL Group Fire Free Village program: fire } \\
\text { management incentives and education for } \\
\text { communities (2014) } \\
\text { Asian Agri Fire Free Village program: fire } \\
\text { management incentives and education for } \\
\text { communities (2016) } \\
\text { Musim Mas Fire Free Village program: fire } \\
\text { management incentives and education for } \\
\text { communities (2016) } \\
\text { Minamas/Sime Darby: fire response and } \\
\text { monitoring and fire management education } \\
\text { for communities (2015) }\end{array}$ & $\begin{array}{l}\text { Roundtable on Sustainable } \\
\text { Palm Oil (RSPO): principles } \\
\text { and criteria (2013) } \\
\text { Asosiasi Amanah: oil palm } \\
\text { smallholders collective } \\
\text { providing support for RSPO } \\
\text { and ISPO certification (2011) } \\
\\
\text { Forest Stewardship Council } \\
\text { (FSC): deforestation } \\
\text { monitoring (2014) } \\
\text { Indonesian Palm Oil Pledge } \\
\text { (IPOP): evaluation and audit } \\
\text { licensing of peat (2015) } \\
\text { Giam Siak Kecil Bukit Batu } \\
\text { Biosphere Reserve (Sinar } \\
\text { Mas in partnership with civil } \\
\text { society and government) } \\
\text { (2009) } \\
\text { Roundtable on Sustainable } \\
\text { Palm Oil (RSPO): principles } \\
\text { and criteria (2007) } \\
\text { Roundtable on Sustainable } \\
\text { Palm Oil (RSPO) (2005) }\end{array}$ \\
\hline Civil society & $\begin{array}{l}\text { Wetlands International: peatland mapping in } \\
\text { consultation with Deltares (2015) } \\
\text { Greenpeace: research and investigation } \\
\text { (2013) } \\
\text { Indonesian Women's Union (Seruni): gender- } \\
\text { based community empowerment (2015) }\end{array}$ & $\begin{array}{l}\text { World Resources Institute: } \\
\text { research and investigation } \\
\text { (2014) } \\
\text { Eyes on the Forest: hotspot } \\
\text { monitoring and investigation } \\
\text { (2015) }\end{array}$ \\
\hline
\end{tabular}




\begin{tabular}{|l|l|l|}
\hline $\begin{array}{l}\text { Riau Forest Rescue Network (Jikalahari): } \\
\text { hotspot monitoring and watchdog activities } \\
(2016)\end{array}$ & $\begin{array}{l}\text { Perkumpulan Elang in } \\
\text { partnership with the Riau } \\
\text { Natural Resources } \\
\text { Conservation Centre: canal } \\
\text { blocking and peat re-wetting } \\
\text { Mitra Insani Foundation: canal blocking } \\
(2012)\end{array}$ & $\begin{array}{l}\text { (2016) } \\
\text { People's Movement to Stop } \\
\text { Haze Singapore (PM.Haze): } \\
\text { peatland restoration (2014) }\end{array}$ \\
\hline
\end{tabular}

